\title{
Konserwatywna krytyka humanitaryzmu. Część druga. Max Scheler, Hannah Arendt
}

DOI: http://dx.doi.org/10.12775/RF.2016.011

\section{Ordo amoris a resentyment - stanowisko Maxa Schelera}

Max Scheler wprowadził do filozoficznego słownika termin humanitaryzm na oznaczenie „mieszczańskiego etosu” zakorzenionego w ideach oświecenia. Fenomenologiczna analiza skłoniła go do przyjęcia tezy, że humanitaryzm w przeciwieństwie do „rdzennego” chrześcijaństwa, które najwyższą wartość przypisuje Bogu, bezkrytycznie absolutyzuje człowieka i popada $\mathrm{z}$ tego powodu w szereg aksjologicznych złudzeń i wypaczeń. Od Nietzschego filozof przejął ideę, że moralność oparta na współczuciu i trosce o dobro powszechne wyrasta z resentymentu, odrzucił jednak tezę zrównującą chrześcijaństwo z religią resentymentu. Według Schelera, Nietzsche nie dostrzegł pozytywnego potencjału zawartego w chrześcijańskiej koncepcji miłości i nie w pełni adekwatnie opisał genealogię etosów zrodzonych z resentymentu, ponieważ błędnie uznał potęgowanie wartości witalnych za najwyższą wartość i najważniejszy cel ludzkiego działania. Scheler umieścił swoją krytykę „moralności resentymentu" w całkiem innym kontekście teoretycznym. Tak jak dla autora Poza dobrem i złem głównym kryterium negatywnej oceny procesu „zafałszowania tablic wartości” były założenia witalistycznej filozofii zwieńczonej koncepcją woli mocy i nadczłowieka, tak u Schelera stałym punktem odniesienia dla krytycznych analiz okazała się fenomenologia. To właśnie fenomenologiczne rozpoznania w sferze aksjologicznej skłoniły autora rozprawy Resentyment a moralność do uka- 
zania fundamentalnej różnicy między „rdzenną etyką chrześcijańską” a oświeceniowym egalitaryzmem. Dlatego też naszą rekonstrukcję schelerowskiej krytyki humanitarystycznego etosu rozpoczniemy od naszkicowania głównych założeń jego „materialnej fenomenologii”.

Fenomenologia stanowi dla Schelera specyficzny rodzaj poznawczego nastawienia wobec świata, który różni się zarówno od „naturalnego nastawienia" przyjmowanego bezrefleksyjnie w codziennym, praktycznym doświadczeniu, jak i od metody naukowej. Akty poznawcze dokonywane $\mathrm{w}$ ramach naturalnego nastawienia mają charakter antropocentryczny - człowiek jest tutaj poniekąd ośrodkiem wszystkich rzeczy. Potoczne poznanie podporządkowane jest pragmatycznym potrzebom i interesom życiowym, służy zatem instrumentalnym celom. Poznanie naukowe opiera się natomiast na obserwacji i skomplikowanej metodzie wyjaśniania i prognozowania, która zawiera w sobie konstruktywno-opisowe elementy indukcji, dedukcji, weryfikacji etc. Dla Schelera istotne jest to, że nauka nie poznaje świata w bezpośredni sposób, lecz odnosi się do pewnych wytworzonych przez siebie konstrukcji czy modeli rzeczywistości. W przeciwieństwie do obu wymienionych nastawień poznawczych fenomenologia dostarczać ma poznania bezpośredniego, asymbolicznego, opartego na ewidencji „czystej naoczności”, do której prowadzi zabieg epoche i redukcja eidetyczna. Co dla nas najważniejsze, fenomenologia $\mathrm{w}$ przeciwieństwie do nauki nie może być aksjologicznie neutralna, wymaga bowiem spełnienia dwóch podstawowych warunków: 1) przyjęcia określonej postawy etyczno-emocjonalnej (w akt poznawczy powinna być zaangażowana całość funkcji duchowych i emocjonalnych podmiotu, który musi: zreintegrować oddzielone formy naoczności, opanować impulsy popędowe zakłócające proces poznawczy, abstrahować od ukrytych przesłanek i interesów poznawczych, poniechać projektowania własnych oczekiwań na badany przedmiot etc.) oraz 2) rozwinięcia wy sublimowanej intuicji aksjologicznej, która będzie w stanie rozpoznać ujawniające się w poznaniu fenomenologicznym wartości oraz specyficzne, zachodzące między nimi relacje.

Zabieg epoche polegający na: 1) zawieszeniu sądów egzystencjalnych na temat rzeczywistości oraz wszystkich bazujących na nim przeświadczeń, 2) wygaszeniu odczucia „pierwotnego oporu”, który rodzi naturalne wrażenie realności świata ${ }^{1}$, otwiera przed fenomenologiem sferę czystej

1 Według Schelera, za elementarne odczucie rzeczywistości odpowiada opór, jaki napotyka pierwotny popęd życiowy zderzający się z ośrodkami sił leżących u podłoża obrazów, które ukazują obiekty zewnętrznego otoczenia. Wygaszenie tego oporu polegające na zahamowaniu pędu życiowego stanowi warunek udanej epoche. Por. M. Scheler, Stanowisko człowieka w kosmosie, tłum. A. Węgrzecki w: Pisma z antropologii filozoficznej i teorii wiedzy, Warszawa 1987, s. 101-102. 
naoczności, bezpośredni dostęp do badanego fenomenu. Redukcja eidetyczna dąży natomiast do wydobycia (a nie projektowania) momentów apriorycznych z konkretnego materiału doświadczenia (np. z przeżyć emocjonalnych). Punktem wyjścia każdej redukcji musi być zatem doświadczenie, ale uchwycenie istoty nie zależy od liczby powtórzeń, które mogą co najwyżej je ugruntować i umocnić. Eidos jako przedmiot czystego oglądu ani nie reprezentuje czegoś innego, ani nie jest przez coś reprezentowany, lecz ukazuje się niejako sam z siebie, całkowicie bezpośrednio i „źródłowo”.

Naszkicowana powyżej koncepcja metody fenomenologicznej budziła i wciąż budzi wiele wątpliwości. W kontekście interesującej nas tematyki resentymentu i humanitaryzmu najważniejsza wątpliwość dotyczy rzekomego antypsychologizmu fenomenologicznego poznania. Pomijając problematyczność samego założenia obiektywnej, źródłowej ewidencji doświadczenia (apodyktycznie narzucającego się, "czystego" wglądu $\mathrm{w}$ istotę rzeczy, który może być wprawdzie zakomunikowany w języku, ale nie ma charakteru intersubiektywnego), możemy zasadnie postawić pytanie, czy przeprowadzona przez Schelera eidetyczna redukcja zjawiska humanitaryzmu nie kryje w sobie - wbrew intencjom filozofa - pewnych wysoce subiektywnych, mimowolnych przesłanek. Jak zobaczymy w dalszej części tekstu, jego krytyka mieszczańskiego etosu wydaje się ocierać $\mathrm{w}$ wielu momentach o jednostronna, idiosynkratyczną awersję, a wręcz o resentyment. W tym miejscu naszych wywodów pozostawimy jednak ten wątek na później i przejdziemy do omówienia fenomenologicznej teorii wartości, która stanowi fundament i główny punkt odniesienia dla jego koncepcji resentymentu.

Zaproponowana przez Schelera fenomenologiczna analiza przypomina pod pewnymi względami Nietzschańską genealogię, ponieważ również autor Poza dobrem i złem próbuje opisać istotę resentymentu, jego „pozaczasowe”, uniwersalne momenty, z drugiej jednak strony, obydwa podejścia różnią się wyraźnie $\mathrm{w}$ sposobie rozłożenia akcentów poznawczych - Schelerowi chodzi przede wszystkim o wydobycie "czystej" istoty, natomiast Nietzsche koncentruje się na "psycho-historycznej" analizie czynników, które w konkretnym procesie dziejowym ukonstytuowały badany fenomen. Innymi słowy, najważniejszą częścią badań genealogicznych jest pytanie o genezę właśnie, o pochodzenie, o historyczne źródła, a nie eksplikacja eidosu danego zjawiska, dlatego też, według Schelera, genealogia połączona z psychologiczną obserwacją nie spełnia ostatecznie wymogów stawianych metodzie fenomenologicznej, która dąży do uchwycenia w akcie ideacji „,ogólnego przedmiotu" prezentującego się bezpośrednio w "strumieniu przeżycia”. Istoty resentymentu nie odsłoni zatem psychologiczny opis rozmaitych form przejawiania się tej emocji, ani jej psychogeneza odwołująca sie do czynników empirycznych (fizjologicznych, społecznych, historycznych etc.). 
Istnieje jeszcze jedna ważna filozoficzna różnica między obydwoma stanowiskami. Nietzsche $\mathrm{w}$ duchu witalistycznej filozofii przyjmuje, że źródłem normotwórczych, kreatywnych aktów psychicznych jest w ostatecznej instancji bezosobowa wola mocy, natomiast według Schelera, wszelkiego rodzaju twórcze procesy zachodzące w ludzkiej psychice pochodzą z duchowego, samoświadomego centrum, które przekracza empiryczny, witalny poziom doświadczenia. W odniesieniu do analizy fenomenu resentymentu wynikają stąd odmienne perspektywy badawcze. Nietzsche postrzega resentyment jako zakłócenie naturalnej, progresywnej tendencji woli do potęgowania sił życiowych, zaś Scheler opisuje go jako iluzję, a w skrajnym przypadku jako „samozatrucie" duchowej osoby, której powołaniem jest realizowanie duchowych, idealnych wartości. Wreszcie w ujęciu fenomenologicznym resentyment okazuje się być negatywem miłości, dla Nietzschego miłość stanowi natomiast pochodną resentymentu.

Kryterium negatywnej oceny humanitaryzmu jest dla Schelera obiektywny porządek wartości odkrywany przez duchową osobę w aktach aksjologicznej intuicji, pośród których szczególną rolę odgrywa właśnie miłość. Za świętym Augustynem filozof pisze w tym kontekście o porządku miłości (ordo amoris) bądź - tym razem za Pascalem - o porządku serca (ordre du coeur), który rządzi się własnymi, alogicznymi, choć apriorycznymi prawami: „Długo nie pamiętano, że obok praw przyczynowych i psychofizycznych zależności życia emocjonalnego od procesów cielesnych istnieją także prawa sensu tzw. wyższych aktów i funkcji emocjonalnych, różniących się od wrażeń uczuciowych"². Resentyment fałszuje obiektywny porządek wartości i ograbia człowieka $\mathrm{z}$ „prawdziwej miłości”, powodując - w przypadku humanitaryzmu - że zamienia się ona w "perwersyjną miłość do ludzi". Prawdziwa miłość jest według Schelera intencjonalnym przeżyciem nakierowanym na odczuwanie wartości, natomiast humanitarystyczne umiłowanie ludzkości to reaktywny stan uczuciowy, który sam w sobie pozostaje nieukierunkowany, dlatego potrzebuje pośrednictwa w postaci określonych wyobrażeń, idei, obrazów - pozbawiony jest zatem autonomii. Resentyment dzięki swojej społecznej „,zaraźliwości”, tj. za sprawą mimetycznego udzielania się innym osobom, może negatywnie wpływać na całe etosy, ale jego oddziaływanie nigdy nie sięga poziomu obiektywnego uniwersum aksjologicznego. Według Schelera, etos (=moralność) ,[...] jest systemem reguł rządzących preferencją samych wartości, systemem ukrytym za konkretnymi ocenami danej epoki i danego ludu - należy go dopiero odkryć jako ich konstytucję moralną"3. Etos oznacza zatem niejawny system preferencji aksjologicznych (a nie wartości!), który determinu-

2 M. Scheler, Istota i formy sympatii, tłum. A. Węgrzecki, Warszawa 1986, s. 5.

3 M. Scheler, Resentyment a moralność, tłum. J. Garewicz, Warszawa 1977, s. 84. 
je powszechne $\mathrm{w}$ danej epoce $\mathrm{i} w$ danym kręgu kulturowym sposoby odczuwania wartości oraz ich hierarchicznego uporządkowania, ale również współkształtuje realia życiowe (obyczajowość, system gospodarczy, prawo, sferę światopoglądową). W swojej historycznie uwarunkowanej postaci stanowi on odzwierciedlenie niezmiennego uniwersum aksjologicznego w ludzkich przeżyciach. „Różne moralności pozostają do owej wieczyście obowiązującej etyki w takim stosunku, w jakim różne systemy słoneczne, np. ptolomejski i kopernikański, pozostają do systemu idealnego, do którego dąży astronomia. System ów, obowiązujący sam przez się, przejawia się bardziej lub mniej adekwatnie w różnych moralnościach" ${ }^{\prime \prime}$ Na empirycznym poziomie moralne usposobienie jednostek zależy ostatecznie od skutków właściwego lub fałszywego odczuwania, a ściślej, preferowania lub stawiania niżej (Nachsetzen) wartości. W obrębie aktów składających się na aksjologiczną intuicję człowieka Scheler wyodrębnia szczególną klasę przeżyć, które nie są aktami poznawczymi, chociaż reprezentują najwyższy stopień emocjonalnego i intencjonalnego życia. Chodzi mianowicie o miłość i nienawiść, czyli spontaniczne (nie będące reakcjami na coś) akty zmierzające do ustanowienia, zachowania lub usunięcia wartości. Owe najwyższe przejawy naszej emocjonalności - jak pisze filozof - „,...] można tylko naocznie uchwycić, ale nie zdefiniować" ${ }^{\prime}$. Miłość i nienawiść nie tyle zatem chwytają już rozpoznane wartości, preferują lub odrzucają jedną z nich na podłożu porównywania, lecz wyróżniają się tym, że posiadają zdolność do odkrywania (ustanawiania) nowych wartości. „Miłość jest raczej intencjonalnym ruchem, w którym na podłożu danej wartości A jakiegoś przedmiotu realizuje się zjawisko jego wyższej wartości"6. Innymi słowy, miłość nie poszukuje w swoim obiekcie nowych, wyższych wartości, ani nie próbuje imaginacyjnie podwyższyć ich rangi, lecz [...] sama miłość jest tym, co w sposób ciągły, mianowicie w trakcie swego ruchu doprowadza do wyłonienia się w przedmiocie wyższej wartości, jak gdyby ona wytryskiwała sama z kochanego przedmiotu, bez żadnej dążeniowej aktywności kochającego"7. To kluczowa różnica między resentymentem a miłością która z natury jest całkowicie wolna od kompulsywnego porównywania wartości, od bezwiednego projektowania zafałszowanych wyobrażeń aksjologicznych, a wreszcie od płynących z bezsilności, reaktywnych emocji. Scheler podkreśla, że miłość nie wypływa z pobudek popędowych, nie jest wyrazem uczuciowych stanów (np. sympatii), ani celowej, wolicjonalnej aktywności - w tym sensie rozwija się niezależnie od podmiotowych intencji i nie wymaga

4 Ibidem, s. 85.

5 M. Scheler, Istota i formy sympatii..., op. cit., s. 236.

6 Ibidem, s. 238.

7 Ibidem, s. 244. 
istnienia swojego obiektu. Ponadto, w przeciwieństwie do humanitarystycznego altruizmu, nie kieruje się ku wszystkim bez wyjątku ludziom (jako reprezentantom gatunku), lecz ku duchowej osobie i to tylko o tyle, o ile jest ona nosicielem wyższych wartości i posiada zdolność do ich realizowania. Ordo amoris stanowi zatem doskonałe przeciwieństwo moralności bazującej na społecznych emocjach. Zanim przejdziemy do omówienia kwestii humanitaryzmu, przyjrzyjmy się jeszcze fenomenologicznej eksplikacji resentymentu.

Scheler w znacznej mierze powtarza ustalenia Nietzschego, jednakże psycho-społeczna genealogia stanowi dla niego zaledwie wstęp do „właściwego" eidetycznego opisu resentymentu. W kilku miejscach pracy Resentyment a moralność wskazuje wprawdzie określone społeczne uwarunkowania sprzyjające rozwojowi tego afektu, ale jego wyjaśnienia mają charakter ogólnych, szkicowych uwag. Między innymi stwierdza, że do upowszechnienia się resentymentu we współczesnej kulturze przyczyniła się specyfika gospodarki wolnorynkowej, która wzmaga zachowania rywalizacyjne uczestniczących w niej aktorów społecznych. Skrajnym przykładem takiej rywalizacyjnej postawy jest dla filozofa arywizm - (nad)aktywność nastawiona na konkurencję dla niej samej. Jak pisze Scheler: „Arywistą jest [...] ten, dla kogo celem dążeń jest przewyższenie innych w rzeczywistości lub w domniemaniu i dla kogo cel ten stoi ponad jakąkolwiek wartością rzeczową; człowiek, dla którego każda rzecz staje się tylko nieistotną okazja, by pozbyć się przy tego rodzaju porównaniu dokuczliwego uczucia, że nie dorównuje"s. Innym czynnikiem sprzyjającym upowszechnianiu się resentymentu jest dla Schelera konkurencja międzypokoleniowa. Promowana w kapitalizmie idea ciągłego postępu i związane z nią dążenie do maksymalizacji wydajności zmieniają tradycyjną relację między pokoleniami. Szybkość zmian kulturowych powoduje, że starsze pokolenie stopniowo traci autorytet i przegrywa konkurencję z młodszym, bardziej elastycznym pokoleniem. Zmarginalizowana starsza generacja staje się podatna na resentyment, na irracjonalne odczucie zawiści wobec wszystkiego, co uosabia młodość. Rozwojowi resentymentu służy ponadto liberalny system władzy współczesnych demokracji. Ośrodkami szczególnej kumulacji tego afektu sa, zdaniem filozofa, parlamenty, które gromadzą niewykwalifikowanych, obarczonych poczuciem niskiej wartości polityków9

Jak już wspomnieliśmy Scheler koncentruje się w swoich analizach resentymentu nie tyle na genezie, lecz na uchwyceniu ahistorycznej istoty tego fenomenu i tutaj właśnie napotykamy najważniejszą trudność natury interpretacyjnej, ponieważ zaproponowany przez niego eidetyczny opis nie jest jednoznaczny pod względem metodologicznym -

8 M. Scheler, Resentyment..., op. cit., s. 49.

9 Ibidem, s. 59. 
niekiedy trudno bowiem rozstrzygnąć, czy dane twierdzenie należy do porządku fenomenologicznej eksplikacji, czy też stanowi rezultat analiz genealogicznych. Mając na uwadze wspomnianą trudność, przedstawimy poniżej najważniejsze rezultaty jego rozważań.

Niezależnie od swoich konkretnych, przygodnych przyczyn resentyment charakteryzuje się, zdaniem Schelera, następującymi „istotnościowymi momentami":

1. Zakłada stłumienie odruchów uczuciowych (nienawiść, złośliwość, odruch zemsty, mściwość, zazdrość, szyderstwo etc.), które, nie znajdując możliwości rozładowania, tworzą „[...] pewne trwałe skłonności do określonego rodzaju złudzeń co do wartości i odpowiadających im sądów wartościujących"10.

2. Zahamowanie odruchu zwrotnego (czyli reakcji na realne lub wyimaginowane zagrożenie) rodzi w osobie opanowanej przez resentyment odczucie bezsilności.

3. Świadomość niemocy w połączeniu z gwałtownością emocji powoduje, że resentyment stopniowo traci odniesienie przedmiotowe i kieruje się ku samemu podmiotowi, który ulega emocjonalnemu „samozatruciu”.

4. Ocena aksjologiczna motywowana resentymentem opiera się zawsze na porównywaniu wartości własnej z cudzą.

5. Niemożliwość zrealizowania upragnionej wartości przez podmiot resentymentu prowadzi do a) iluzorycznego pomniejszenia wartościowych cech obiektu porównań lub b) niedostrzegania tych cech lub c) zafałszowania samych wartości (odwrócenia obiektywnej hierarchii aksjologicznej - degradacji wyższych wartości i wywyższenia wartości niższych).

Do wymienionych „istotnościowych momentów” możemy dołączyć jeszcze jedną (psychologiczną?) cechę resentymentu, jaką jest jego podatność na udzielanie się innym osobom i większym grupom społecznym. Owa „zaraźliwość” resentymentu powoduje, że w sprzyjających okolicznościach może on wpłynąć na kształtowanie się nie tylko poszczególnych wartościowań, ale całej moralności, jak, zdaniem Schelera, miało to miejsce $\mathrm{w}$ przypadku etosu mieszczańskiego. Powyższe zagadnienie wpisuje się ściśle w problematykę humanitaryzmu, którą omówimy w następnym rozdziale.

\section{Schelerowska kryłyka humanitaryzmu}

Według Schelera naturalnym mechanizmem hamującym rozprzestrzenianie się resentymentu jest stabilna, hierarchiczna struktura społeczna.

10 Ibidem, s. 34. 
Gdy granice między stanami czy klasami są wyraźne, a różnice między nimi głębokie (w znaczeniu ekonomicznym, obyczajowym, prawnym i politycznym), resentyment krąży w poszczególnych sferach społeczeństwa i nie wydostaje się „na zewnątrz”. Wzorcowym przykładem takiej struktury społecznej jest dla filozofa średniowieczny system feudalny. Jednostka żyje w nim przypisana (przez „opatrzność") do określonego miejsca, do określonej roli społecznej i bezwiednie ulega autorytetowi władzy świeckiej i duchowej, co zapobiega kompulsywnemu porównywaniu się z osobami znajdującymi się na wyższym piętrze drabiny społecznej. Gdy granice społeczne zacierają się z powodu równouprawnienia wszystkich obywateli, ale zachowane zostają różnice w zakresie faktycznej władzy, pozycji ekonomicznej i statusu społecznego, powstają idealne warunki sprzyjające upowszechnianiu się resentymentu. Z powyższej obserwacji Scheler wyprowadza następującą prawidłowość: im większa dysproporcja między roszczeniami do równości a rzeczywistym stanem rzeczy, tym większa intensywność społecznego oddziaływania resentymentu. Tego rodzaju napięcie powstało, zdaniem Schelera, w dobie oświecenia wraz z narodzinami racjonalizmu, zwłaszcza po Rewolucji Francuskiej. Dotychczasowy chrześcijański ideał miłości duchowej opartej na bezwarunkowej miłości do Boga przekształcił się w racjonalistyczny i naturalistyczny imperatyw umiłowania ludzkości jako gatunku biologicznego obdarzonego uniwersalnym rozumem. Nowy ideał altruizmu zasadzającego się na sympatii do każdego bez wyjątku człowieka wyparł chrześcijańską agape i sprowadził miłość do poziomu zmysłowego stanu uczuciowego. Nowożytna miłość do człowieka (humanitas, filantropia) przybrała postać rewolucyjnego patosu, który zwrócił się przeciwko tradycji, panującym instytucjom i obyczajom, aby wyzwolić nowa, cieszącą się zmysłowym szczęściem i dobrostanem ludzkość. W pracy Istota i formy sympatii filozof stwierdza, że humanitas , ,[...] nie była prawdziwym, autonomicznym ruchem miłości, $\mathrm{z}$ własnym pozytywnym fundamentem $\mathrm{w}$ istocie ducha ludzkiego, lecz tylko tezą walki i protestu przeciwko, z jednej strony, chrześcijańskiej miłości do osoby i Boga, a z drugiej, przeciwko miłości ojczyzny"11. Humanitaryzm dążący do zrealizowani dobra powszechnego wszystkich ludzi ograbia doświadczenie miłości z dwóch podstawowych wymiarów czasowych: 1) z odniesienia do przeszłości, jakie w społeczeństwach opartych na religii chrześcijańskiej zapewniała tradycja, pamięć o zmarłych i wyobrażenie kosmicznego uniwersum obejmującego porządek ziemski i ponadzmysłowy (hierarchia anielska) oraz 2) z odniesienia do przyszłości, jakiego niegdyś dostarczały idee „Królestwa Bożego” i „życia po śmierci". Miejsce konkretnego indywiduum, uchwytnego „tu i teraz" bliźniego zajęło abstrakcyjne wyobrażenie zbiorowości. Przede

11 M. Scheler, Istota i formy sympatii..., op. cit., s. 162. 
wszystkim zaś wyparty został wymiar duchowy miłości (odniesienie do osobowego centrum człowieka), zamiast niego pojawiła się emocjonalna relacja wytworzona na drodze „zarażenia” psychicznego. „Jądrem nowego humanitaryzmu jest cierpienie na widok bólu i radość na widok doznawanej radości. [...] Współodczuwanie zostaje sprowadzone albo do sztucznego wnikania w stan duszy cudzej na zasadzie pytania: 'co byś czuł, gdyby się to tobie przydarzyło?' i do odtworzenia stanów stanów uczuciowych, które przeżywaliśmy sami w analogicznej sytuacji”"12. Scheler utrzymuje ponadto, że w nowożytnym altruizmie często do głosu dochodzi stadny instynkt nastawiony na przetrwanie gatunku, który możemy zaobserwować w społecznych zachowaniach zwierzą ${ }^{13}$.

Filozof, krytykując humanitaryzm, rezygnuje z szczegółowej analizy genealogicznych uwarunkowań, które doprowadziły do jego powstania. Chodzi mu raczej o przedstawienie tego fenomenu na tle szerszych ruchów kulturowych i ekonomicznych. Jego uwagi na ten temat są nader ogólne; stwierdza między innymi, że racjonalizm i wywodzący się $\mathrm{z}$ niego nowy paradygmat mechanistycznej nauki, nowożytny humanizm oraz początki nowej kapitalistycznej gospodarki przeobraziły panujące dotąd reguły preferencji wartości, tworząc zręby nowej moralności, która przybrała postać humanitaryzmu.

Scheler utrzymuje, że duży wpływ na jego powstanie miała również reformacja, a zwłaszcza doktryna Martina Lutra. Z jednej strony, luteranizm zdecydowanie przeciwstawiał się świeckiej idei powszechnego szczęścia i braterstwa wszystkich ludzi, głosząc doktrynę, że człowiek jest z natury grzeszny, bezsilny i bez łaski Boga nie może liczyć ani na zbawienie, ani na pomyślność w tym życiu. $Z$ drugiej jednak strony, reformacja kładła nacisk na to, że zbawienie człowieka zależy od bezpośredniej (samotnej) relacji między jednostką a Bogiem. Z tego powodu jak sądzi Scheler - znaczenie utraciła „rdzennie” chrześcijańska „zasada solidarności" - zakorzenienie człowieka we wspólnocie wiary i miłości, $\mathrm{w}$ instytucjonalnym porządku władzy kościelnej, tradycji i autorytetu. Przede wszystkim zaś znaczenie utraciły własne działania („,dzieła”) człowieka, ponieważ w świetle nauk Lutra wszystko zależy ostatecznie od wszechmocnego Stwórcy świata. Owa dyskredytacja dotyczyła nie tylko uczynków mających na celu poprawę własnego lub powszechnego dobrobytu czy moralnych decyzji i wyborów, ale również - co dla Schelera najważniejsze - szczególnego „dzieła”, jakim jest akt miłości. "Z chwilą jednak, gdy [Luter] zaprzeczył, by miłość - podobnie jak wiara - miała charakter nadnaturalny i pierwotny, i gdy nawet wewnętrzny akt miłości zaliczył do sfery 'dzieł', które nie prowadzą naprawdę do zbawienia, zanegował on chrześcijańską ideę miłości głębiej jeszcze niż

12 M. Scheler, Resentyment..., op. cit., s. 133, 134.

13 Ibidem, s. 135. 
zwalczana przez niego instytucja [kościoła] i przyczynił się silniej jeszcze niż Kościół do powstania czysto nowożytnego humanizmu, który w miłości widzi siłę czysto ludzką, cielesno-zmysłową"14. Luter postawił zatem na wiarę kosztem "miłości do siebie samego i bliźniego swego", co w konsekwencji doprowadziło do oddzielenia religii od moralności. Moralne zobowiązania wobec innych okazały się bowiem wtórne wobec imperatywu indywidualnego zbawienia.

Według Schelera, humanitaryzm narodził się z heterogenicznych źródeł kulturowych, ale ostatecznie przybrał stosunkowo jednolitą postać pod szyldem umiłowania ludzkości. Filozof opiera swoją krytykę tego etosu na wątpliwym, jak pokażemy w dalszej części tekstu, przekonaniu, że filantropia „istotowo" wypływa z resentymentu i nie służy realizacji autentycznych, pozytywnych wartości, ponieważ jej główną siłą motywacyjną jest wspomniana "nienawiść wobec Boga i tradycji”, wyparcie autentycznej, chrześcijańskiej miłości.

Z dzisiejszej perspektywy, ten wątek krytyki humanitaryzmu wydaje się być podszyty idiosynkratyczną awersją filozofa, a wręcz resentymentem wobec politycznych działań mających na celu poprawę warunków życia oraz poszerzenie zakresu praw i swobód obywatelskich. Nawet jeśli zgodzimy się z negatywną oceną pewnych przejawów „ideologii braterstwa i równości", to trudno nam będzie jednak zaakceptować tak jednostronne, pozbawione merytorycznego uzasadnienia odrzucenie postawy etycznej, która w praktyce przyczyniła się do wielu pozytywnych zmian w życiu społecznym. Poniżej przedstawimy "argumenty" filozofa na poparcie tezy o fałszywości zasady świeckiego „umiłowania ludzkości".

Po pierwsze, humanitaryzm jest, według niego, iluzją ",[...] opartą na nienawiści do siebie i na ucieczce od siebie"15. Na uzasadnienie tak skrajnie emocjonalnego twierdzenia filozof odwołuje się do spostrzeżenia Pascala, że człowiek odczuwający „wewnętrzną pustkę" często szuka desperacko ucieczki w zewnętrznej aktywności, w iluzorycznym zabieganiu o dobro innych. Następnie fenomenolog wskazuje przykład patologicznego altruizmu, który $\mathrm{w}$ "słabszym stopniu” występuje również w humanitaryzmie: „Chory nie koncentruje się wtedy już na własnej egzystencji, zaniedbuje wszystkie własne sprawy, wciągnięty jest całkowicie w cudze życie - cierpi nad tym"16. Przejawem takiej patologii jest również ",[...] postać zbiorowego szaleństwa, np. wśród rosyjskiej inteligencji, a zwłaszcza akademickiej młodzieży męskiej i żeńskiej, która swoją chorobliwą żądzę poświęcenia oraz ucieczkę przed samym sobą z lubością wyraża w celach politycznych i społeczno-politycznych, a na-

14 Ibidem, s. 154.

15 Ibidem, s. 146.

16 Ibidem, s. 147. 
stępnie wykłada własną chorobliwość jako heroizm moralny"17. Kolejny przykład jeszcze bardziej ma zbliżyć nas do „esencji” humanitaryzmu Scheler odnosi się tym razem do "coraz częściej spotykanego" typu polityka socjalnego, który analogicznie jest godnym pożałowania, pustym uciekinierem przed samym sobą ${ }^{18}$.

Te dość swobodne i nieco groteskowe (gdy zestawimy ich apodyktyczność z brakiem jakiegokolwiek merytorycznego uzasadnienia) tezy kulminują w stwierdzeniu (będącym wyrazem eidetycznego wglądu?), że prawdziwym jądrem humanitaryzmu , ,[... jest zjawisko psychospołecznego zwyrodnienia"19. Następnie padają kolejne (istotnościowe?) charakterystyki humanitas: „,zniewieściałe zmysłowe uczucie bezkrytycznego udziału w życiu cudzym" ${ }^{20}$ oraz pozorne dążenie do "popierania życia”, które w istocie jest „wyrazem schyłku życia”"21 „Zwyrodnienie” humanitaryzmu maskowane ideologią empatycznej dobroczynności bierze się, według Schelera, stąd, że swój główny cel - dobro powszechne - sprowadza do wartości instrumentalnych, dlatego ,[...] jego oceny wartości są faktycznie niesłychanym zafałszowaniem tabel wartości, albowiem nadrzędną wartość miłości oraz szczęście związane z jej aktem podporządkowuje zarazem dowolnej rozkoszy zmysłowej - i to niezależnie od od wartości osoby, która jej doznaje"22.

Wydaje się, że w całym powyższym wywodzie Scheler, znany z przenikliwości i precyzji argumentacji, poddał się oddziaływaniu "niskich" emocji i zrezygnował z prowadzenia logicznego dyskursu. Zastanówmy się, jakie praktyczne konsekwencje wynikają z przedstawionego powyżej „rozumowania”. Niewątpliwie moglibyśmy jeszcze zaakceptować (o ile bylibyśmy zwolennikami zaproponowanej przez niego wersji chrześcijaństwa) tezę, że humanitas stanowi przeciwieństwo „prawdziwej miłości”. Jednakże nawet $\mathrm{w}$ tym przypadku nasunie się nam nieodparcie pytanie, czy humanitarystyczna instrumentalizacja umiłowania ludzkości faktycznie musi płynąć z nienawiści do Boga i ucieczki przed samym sobą? A jeśli nawet zgodzimy się, że tak jest, to czy przekreśla to pozytywną wartość filantropijnego działania? Scheler obstaje jednoznacznie przy tym, że każda aktywność społeczna, która ma na celu zmysłowe szczęście i dobrostan innych ludzi, a przy tym nie kieruje się ku Bogu, oznacza psychospołeczne zwyrodnienie i jest wyrazem schyłku życia. Czy istnieje jakiś merytoryczny argument, który

\footnotetext{
Ibidem.

Ibidem.

19 Ibidem, s. 148.

Ibidem.

1 Ibidem, s. 149.

Ibidem, s. 148/49.
} 
mógłby uzasadnić takie przekonanie? Uznajmy to pytanie za retoryczne i pozostawmy je bez odpowiedzi.

Krytyka humanitaryzmu przeprowadzona przez Schelera jest na całe szczęście dość kompleksowa i poza ewidentnymi „mieliznami”, odnaleźć można w niej ustalenia warte dyskusji. Jak zauważa filozof, nowożytna idea filantropii "grzeszy" abstrakcyjnościa, jej obiektem jest bowiem gatunek ludzki - wszyscy ludzie bez względu na indywidualne różnice. Takie ogólne, inkluzywne ujęcie może sprzyjać relatywizmowi etycznemu, ponieważ na drugi plan schodzi w nim rozwój moralny jednostki, zacierają się granice pomiędzy różnymi poziomami wartości. Celem samym w sobie stają się tutaj wartości witalne takie jak dobrobyt, bezpieczeństwo socjalne, opieka zdrowotna, etc., natomiast wartości duchowe, wysokie standardy moralne zaczynają jawić się jako ekskluzywny naddatek, przywilej ludzi, którzy uporali się z problemami materialnymi i na własne życzenie rozwijają swoją duchowość. Ponadto w humanitaryzm wpisane jest napięcie między solidarnością społeczną a skrajnym indywidualizmem; na płaszczyźnie prawnej przejawia się ono we współczesnych demokracjach liberalnych jako rozdźwięk między uniwersalizmem praw człowieka a partykularyzmem praw obywatelskich. Ta sprzeczność zaburza - na poziomie praktycznej realizacji - dążenie do globalnej równości i braterstwa i w znacznej mierze przyczynia się do powstania społecznej anomii. Tendencja do uniwersalizacji niweluje różnice, homogenizuje jednostki, natomiast tendencja do indywidualizacji atomizuje społeczeństwo, narusza więzy wspólnotowe. Obydwie tendencje popadają zatem w sprzeczność i prędzej czy później pociągają za sobą realne konflikty (obyczajowe, światopoglądowe, ekonomiczne, prawne).

Słuszna wydaje się również obawa Schelera, że ukrytą przesłanką utylitarystycznie pojętej idei dobra powszechnego jest zasada "cel uświęca środki", która daje przepustkę dla działań mających niewiele wspólnego z moralnością.

Filozof krytykuje wreszcie idee humanitarystyczne za to, że odwołują się one do sympatii i pokrewnych stanów uczuciowych, które z natury są zmienne i dlatego nie mogą stanowić stabilnego oparcia dla rozwoju etycznej postawy i politycznej praktyki.

Powyższy zarzut potraktujemy jako ostatni moment naszej rekonstrukcji koncepcji Schelera, a zarazem jako punkt wyjścia dla omówienia stanowiska Hannah Arendt, która wprawdzie nie ustosunkowała się explicte wobec kwestii humanitaryzmu, ale jej wizja polityczności i wynikająca z niej krytyczna diagnoza demokracji liberalnej wpisuje się w konserwatywny dyskurs, który piętnuje dominujący współcześnie eudajmonizm prosocjalnej polityki opartej na ideach równości i powszechnego dobrobytu. 


\section{Zagubiony wymiar polityczności - Hannah Arendt}

Dotąd przyglądaliśmy się krytyce humanitaryzmu uprawianej z dwóch perspektyw: nietzscheańskiej filozofii życia i schelerowskiej fenomenologii wartości. Hanna Arendt umieszcza omawianą problematykę w kontekście teorii polityki. Filozofka argumentuje, że zmiana paradygmatu uprawiania i rozumienia polityki zainaugurowana $w$ filozofii przez Thomasa Hobbesa spowodowała, iż na pierwszy plan w sferze publicznej wysunęły się zagadnienia ekonomiczne - a później, po Rewolucji Francuskiej - prymat zyskała tak zwana kwestia socjalna: pomyślność i dobrobyt obywateli liberalnych demokracji, którzy zostali wprawdzie zrównani pod względem prawnym, ale równocześnie $\mathrm{w}$ większości utracili bezpośredni dostęp do sprawowania władzy. Zmiana, która nastąpiła w porządku społecznym i politycznym wiązała się, zdaniem Arendt, z głębszymi, historycznymi przekształceniami w obrębie ludzkiej kondycji.

Ostatnie pojęcie wymaga krótkiego wyjaśnienia. Filozofka utrzymuje mianowicie, że „kondycja” w przeciwieństwie do "natury” człowieka jest przygodna, uwarunkowaną wieloma czynnikami konstelacją ludzkich aktywności. Nie wiemy, kim jest człowiek w swej „naturze”, ale jesteśmy w stanie wydedukować - na podstawie jego poczynań w świecie - kim może się stać jako istota działająca. Człowiek stanowi zatem sumę zdeterminowanych historycznie możliwości, które wyznaczają nieprzekraczalny horyzont jego egzystencji. Według Arendt ów horyzont wyznaczają następujące formy aktywności: praca (ponos), wytwarzanie (poiesis), działanie (praxis), myślenie, sądzenie, poznanie, chcenie. W interesującym nas kontekście kluczową rolę odgrywa "praca” i "działanie". Praca odsyła bezpośrednio do sfery witalnej i łączy się z roszczeniami do szczęścia, dobrobytu i zdrowia, natomiast działanie ściśle splecione z mową odpowiada za tworzenie sfery intersubiektywnie podzielanego sensu i historii, a przede wszystkim stanowi główne medium realizacji ludzkiej wolności. Nie mamy miejsca, aby dokładnie omówić antropologiczne założenia filozofii Arendt, dlatego w dalszej części artykułu skupimy się jedynie na pokazaniu tego, w jaki sposób filozofka definiuje obydwie sfery vita activa, dochodząc do wniosku, że współcześnie popadają one w ostry konflikt, który znacząco wpływa na nasze społeczne i polityczne życie.

Gdy umieścimy opisany przez Schelera humanitaryzm w ramach filozofii Arendt, okaże się, że jego egzystencjalne korzenie sięgają elementarnej sfery działań mających na celu zaspokojenie konieczności życiowych. To właśnie praca (ponos) odpowiada za biologiczne przetrwanie ludzkiego ciała i całego gatunku. Człowiek jest integralną częścią 
biouniwersum i podlega jego stałym, powtarzalnym rytmom. W tym sensie jako istota przyrodnicza wiedzie on egzystencję animalna, skupiając się na zaspokajaniu nawracających potrzeb życiowych. Kryje się $\mathrm{w}$ tym zatem nieuchronny automatyzm biologicznych procesów, swoiste krążenie w fizjologicznej figurze "wiecznego powtórzenia”. Praca pozwala nam żyć na elementarnym, wegetatywnym poziomie, a zarazem stanowi źródło naszych witalnych roszczeń, które kulminują w niezbywalnym pragnieniu zmysłowego szczęścia. Charakterystyczna dla pracy jest nietrwałość jej wytworu: uprawa roli, pielęgnacja ciała, utrzymywanie porządku, konsumpcja wydają się nie mieć końca ani początku. Według Arendt ponos nie daje nam poczucia sensu istnienia, nie tworzy również wartości wykraczających poza partykularne interesy. Jako animal laborans człowiek nie wznosi się do poziomu duchowego, lecz nieustępliwie obstaje przy biologicznym trwaniu ${ }^{23}$.

Działanie (praxis) stanowi poniekąd odwrotność pracy, odzwierciedla bowiem aspekt wielości (a nie jednostkowości) ludzkiej kondycji, tworzy warunki dla pamięci i historii, a zatem dla "sensu”, który przekracza wąskie granice indywidualnego istnienia. Według Arendt praxis stanowi jedyną prerogatywę człowieka, ponieważ przerywa kołowrót biologicznych procesów i otwiera niespotykaną w świecie zwierzęcym perspektywę wolności. Zdolność do działania zakłada, z jednej strony, wspomnianą wielość, tj. wspólnotę innych równych, a zarazem różnych (niepowtarzalnych) ludzi, a z drugiej strony, opiera się na aspekcie „narodzin" (natality) ludzkiej kondycji. Kategoria natality posiada u Arendt szczególne znaczenie, wskazuje nie tylko na oczywisty fakt narodzin, ale przede wszystkim na właściwą człowiekowi zdolność do zapoczątkowania czegoś nowego. Filozofka odwołuje się tutaj do greckiego pojęcia archein - rozpoczynać, prowadzić, wprawiać w ruch i rządzić. „Ludzie są initium, nowymi przybyszami, którzy dają czemuś początek na mocy samych swoich narodzin, dlatego podejmują się czegoś nowego i skłonni są do działania" ${ }^{24}$. Przerwanie nawykowego, opartego na rutynie dnia codziennego łańcucha zachowań i decyzji otwiera przed człowiekiem perspektywę wolności. To zaś możliwe jest w specyficznej przestrzeni wzajemnych, międzyludzkich powiązań, w której uznaje się wspólne dobro i odmienność (alteritas) działających podmiotów. „Mowa i działanie ujawniają ową unikalną odmienność. Przez nie ludzie wyróżniają się, a nie tylko są różni; są to sposoby pojawiania się sobie istot ludzkich nie jako fizycznych przedmiotów, ale jako ludzi"25. Tą przestrzenią jest dla Arendt sfera publiczna - obszar tego, co wspólne (koinon), na którym jednostka ukazuje się najszerszemu możliwemu kręgowi odbiorców,

23 Por. H. Arendt, Kondycja ludzka, tłum. A. Łagodzka, Warszawa 2000, s. 87-150.

24 Ibidem, s. 195.

25 Ibidem, s. 194. 
wystawia się na ich ocenę i podejmuje „walkę" o dobro całej zbiorowości, używając wyłącznie "symbolicznej broni”, jakiej dostarcza język. Sfera publiczna stanowi tym samym warunek możliwości politycznego działania, a co za tym idzie - polityki jako takiej. W działaniu (każde autentyczne działanie jest dla Arendt działaniem politycznym) na pierwszy plan wysuwa się mowa jako sposób reagowania na rzeczywistość, jako środek wywoływania w niej realnych skutków, zmian, a nie tylko jako środek perswazji. Działanie i mowa odbywają się zawsze pomiędzy ludźmi, tworzą sieć interpersonalnych powiązań, które - przynajmniej częściowo - przeciwdziałają kruchości ludzkiej egzystencji.

Cechą charakterystyczną praxis jest nieprzewidywalność jej rezultatów. Działając zmierzamy wprawdzie do osiągnięcia określonych celów, jednakże nigdy nie mamy pewności, co przyniosą nam nasze decyzje, dlatego potrzebujemy różnego rodzaju sojuszy, umów, słownych gwarancji, które długoterminowo stabilizują naszą aktywność i nasze motywacje.

Podmiot, który odsłania się dzięki mowie i działaniu, zaczyna tworzyć swoją (ale również zbiorową) historię, pewien ujawniający się z upływem czasu, intersubiektywny sens, który wykracza poza jego biograficzną prywatność, a co najważniejsze, zaczyna dzięki temu urzeczywistniać to, ",kim jest" - potencjał zawartych w nim predyspozycji i zdolności. Sfera publiczna stanowi rodzaj sceny, na której działający aktorzy odgrywają wspólną historię, nie będąc jednak jej "reżyserami”. Sens, puenta tej historii, pozostaje przed nim zakryta, co nadaje całej sytuacji odcień dramatyzmu, ale i nadziei. Ta ostatnia bardzo wyraźnie dochodziła do głosu u Greków, którzy w swoich poczynaniach politycznych kierowali się pragnieniem nieśmiertelności (upamiętnienia i uznania ze strony przyszłych pokoleń).

Arendt zdecydowanie oddziela wolną od przemocy sferę publiczną od apolitycznej sfery prywatnej, w której rozgrywa się codzienna walka o przetrwanie. W granicach prywatności dopuszczalna jest przemoc uznana przez filozofkę za przedpolityczny sposób uwalniania się od konieczności życiowych, nieprzerwanie toczy się w niej żmudna praca nastawiona na zaspokajanie cielesnych potrzeb, a tym samym nieuchronnie panuje tam przymus, żywiołowo rozwijają się niekontrolowane relacje podległości i dominacji. Jednostka zamknięta w domowym oikos zabiega głównie o „kwestie materialne” związane z szeroko pojętą ekonomia z troską o dostatek, o zdrowie i pomyślność członków najbliższej rodziny. Arendt podkreśla deprywacyjny charakter prywatności, która, jej zdaniem, pozbawia człowieka najwyższych zdolności, ograbia go z własnej historii, z możliwości samorealizacji, a wreszcie z sensu, który mógłby wyznaczyć cel egzystencji wykraczający poza partykularne interesy. $Z$ drugiej strony, wskazuje, że jedynie w sferze prywatnej może pojawić się głębia jednostkowego doświadczenia, bo- 
gactwo emocjonalnego przeżywania. To właśnie prywatność tworzy podłoże dla uczuć odpowiadających za moralną wrażliwość, takich jak wstyd czy empatia. Kluczowe w każdej postawie etycznej "czynienie dobra" zakłada bowiem skrytość (w zgodzie z biblijnym przysłowiem: "niech lewica twoja nie wie, co prawica twoja czyni"), jakiej pozbawiona jest sfera publiczna: gdy dobry uczynek, ale również akt miłości, staje się publiczny, traci swoją sprawczą moc, dewaluuje się.

W Kondycji ludzkiej Arendt opisuje historyczne zmiany, jakim podległa sfera publiczna i prywatna. W dobie oświecenia doszło, według niej, do wyraźnego przekształcenia sfery intymnej, która zyskała odtąd ogromne znaczenie dla ludzkiej samowiedzy. Jednostka zaczęła bowiem systematycznie „uczyć się" - poprzez lekturę, dyskusję, towarzyską inscenizację - własnego „wnętrza”, rozwijać emocje, dostrzegać i doceniać uroki petit bonheur - „małego szczęścia” pośród zapomnianych drobiazgów wypełniających intymną codzienność. A co najważniejsze rozkwitająca podówczas nowa „wrażliwość serca” stała się źródłem socjalnych i politycznych roszczeń, które odezwały się potężnym echem w Rewolucji Francuskiej.

Transformacji, a w zasadzie atrofii, uległa również sfera publiczna. Według Arendt, nowożytność doprowadziła do kresu trwający od śmierci Peryklesa proces wypierania polityczności przez czysto społeczny wymiar życia zbiorowego. Najważniejszym symptomem tego procesu było wprowadzenie do sfery publicznej czynności związanych wcześniej z oikia, czyli działalności gospodarczej i finansowej. Ekonomizacja polityki doprowadziła do tego, że stała się ona publiczną organizacją życia. Głównym przedmiotem jej troski są bowiem odtąd życiowe potrzeby konkurujących ze sobą obywateli, a przede wszystkim wspólne bogactwo chronione przez powołane w tym celu rządy. Innymi słowy polityka przekształciła się $\mathrm{w}$ swoje przeciwieństwo - w technikę zarządzania gospodarką i upublicznionym procesem pracy, a tym samym $\mathrm{w}$ technikę kontroli i nadzoru nad witalną energią (siłą produkcyjną) społeczeństwa i najskrytszymi pragnieniami jego członków.

Uwięziona dotąd $\mathrm{w}$ sektorze prywatnym praca oswobodziła się z biologicznych ograniczeń do tego stopnia, że współczynnik wzrostu przerósł procesy rozpadu, które niegdyś równoważyły produkcję dóbr konsumpcyjnych. W rezultacie nastąpił - jak pisze Arendt - nienaturalny wzrost tego, co naturalne. Społeczna organizacja pracy doprowadziła do gwałtownego wzrostu ogólnego bogactwa i poziomu życia, co z kolei pociągnęło za sobą niezwykły przyrost demograficzny. Dlatego też Arendt wskazuje, że ze względów czysto ilościowych umasowione społeczeństwa ograniczają możliwość działania politycznego. Społeczeństwo wymaga przewidywalnych, znormalizowanych, przebiegających według dającego się wyliczyć algorytmu działań, które wykluczają spontaniczność i wybitne osiągnięcia. Tendencja do niwelowania różnic 
między jednostkami tworzy warunki, w których zanika nie tylko praxis, ale również sfera publiczna. Politycy nie muszą już kierować się ideałem mądrości - phronesis (roztropnym rozpoznaniem życiowej sytuacji), ponieważ najważniejsze znaczenie ma techniczna wiedza jak zbudować sprawnie funkcjonujące instytucje i procedury odgórnie regulujące procesy decyzyjne. Znaczenie traci również klasyczna idea sprawiedliwości na rzecz imperatywu powszechnego dobrobytu i wygody w ramach ustalonego porządku praw. Utylitarystycznie pojęta polityka sprowadza się do techniki urządzania państwa, miejsce wybitnych mężów stanów zajmują natomiast partie grupujące ekspertów, a częściej - konformistycznie nastawionych działaczy, którzy kierują się interesem własnym, a nie dobrem ogółu.

Obydwa opisane powyżej procesy, to jest, nowożytna ekspansja intymności, dzięki której prywatne, subiektywne emocje przeniknęły do sfery publicznej oraz stopniowy zanik tej ostatniej, wyjaśniają przyczyny niezwykłej koniunktury humanitaryzmu w liberalnych demokracjach. Ujmując rzecz zwięźle, możemy powiedzieć, że w perspektywie zarysowanej przez filozofkę humanitaryzm byłby nieudaną próbą aktywizacji politycznej w warunkach ogólnego zaniku polityczności. Taką brzemienną w skutki dla rozwoju demokracji liberalnych próbą mobilizacji politycznej mas były dwie największe rewolucje nowożytności: francuska i amerykańska. Zwłaszcza w tej pierwszej ożyły jednak opacznie pojęte, zdaniem Arendt, idee równości i braterstwa, które przyczyniły się do jej ostatecznego fiaska, mimo że w dłuższej perspektywie czasowej wywołała ona fundamentalne zmiany w życiu politycznym współczesnych społeczeństw.

W kolejnym rozdziale pokażemy, że Rewolucja Francuska (widziana przez pryzmat filozofii Arendt) stała się rodzajem "ć́wiczebnego pola", na którym wzmocniły się i wykrystalizowały idee humanitarystyczne.

\section{Terror współczucia w Rewolucji Francuskiej - narodziny politycznego humanitaryzmu}

Rewolucje są zdaniem Arendt zjawiskiem wyłącznie nowożytnym. Wcześniejsze przewroty, zamachy stanu, rebelie nie miały na tyle radykalnego charakteru, żeby otworzyć perspektywę całkiem nowego ładu politycznego. Celem wcześniejszych buntów społecznych (np. powstań chłopskich) i rewolt stricte politycznych (np. „rewolucyjnej” dyktatury Cromwella) nie była $\mathrm{w}$ istocie zmiana panującego status quo, lecz uzyskanie lepszej pozycji w istniejącym porządku władzy lub wprowadzenie doń pewnych innowacji, które jednak nigdy nie podważały najgłębszych podstaw systemu. 
Arendt proponuje „emfatyczną" definicję rewolucji jako wydarzenia, które przerywa kontinuum historii, niejako rozpoczyna dzieje na nowo, tworząc nigdy wcześniej niesłyszaną opowieść (historię właśnie). Novum, jakie wnosi każda „autentyczna” rewolucja, polega na tym, że tworzy ona przestrzeń intersubiektywnej wolności, że pozwala doświadczyć początków nowego ładu politycznego. Takie doświadczenie było udziałem uczestników obydwu wielkich rewolucji XVIII wieku amerykańskiej i francuskiej. Obydwie rewolucje zaprzepaściły jednak zawarty w nich potencjał emancypacyjny.

Z perspektywy interesującej nas tematyki najważniejsza jest arendtowska analiza przyczyn niepowodzenia rewolucji francuskiej, ponieważ $\mathrm{w}$ niej właśnie najintensywniej ożyły idee humanitaryzmu. Główna konkluzja filozofki - w nieco przejaskrawionej formie - brzmi następująco: rewolucja rozpoczęta na ulicach Paryża zakończyła się fiaskiem z powodu nadmiaru współczucia skumulowanego w wymiarze politycznym. Terror współczucia stał się zatem przyczyną tego, że rewolucjoniści przeoczyli ideę constitutio libertatis i bezwiednie uruchomili spiralę wzajemnej przemocy. Według Arendt głównym impulsem, a zarazem celem rewolucji nie było tylko wyzwolenie francuskiego ludu spod ucisku rządzących i ustanowienie wolności, ale przede wszystkim wyzwolenie procesu życiowego społeczeństwa z jarzma niedostatku, celem stał się zatem dobrobyt, witalna pomyślność, która wcześniej stanowiła przedmiot troski i dążeń ludzi prywatnych, a nie polityki. $\mathrm{W}$ rezultacie kolektywny organizm $\mathrm{i}$ jego potrzeby wydostały się z podziemi prywatności i zyskały rangę dobra publicznego. Według Arendt zjawisko to nie miało $\mathrm{w}$ historii precedensu. Wprawdzie już Arystoteles podkreślał, że interes (sympheron) rządzi ostatecznie i powinien rządzić sprawami polityki, jednakże zmiana polityczna motywowana interesami ekonomicznym nie miała w starożytności na celu zniesienia różnicy między biednymi i bogatymi - tę uznawano bowiem za coś naturalnego, $\mathrm{z}$ natury wpisanego w każdy porządek społeczny.

Dopiero w nowożytności kwestia socjalna zaczęła odgrywać rewolucyjną rolę, przy czym paradoks historii polega na tym, że marzenie o powszechnym szczęściu zamieniło się $\mathrm{w}$ realistyczne przekonanie na obszarze kolonialnej Ameryki, która stała się swoistym azylem i miejscem spotkania ubogich. Tam właśnie zmiana społeczna likwidująca rażącą nędzę poprzedziła zmianę polityczną, dlatego rewolucja amerykańska uchroniła się przed terrorem współczucia wypływającym z troski socjalnej. Chodziło w niej bowiem głównie o zmianę formy władzy, a nie o zmianę społeczną. Stąd też współczucie dla uciśnionych nie odegrało w Ameryce żadnej roli, o czym dobitnie świadczy chociażby brak poczucia solidarności amerykańskich rewolucjonistów z niewolnikami ${ }^{26}$.

\footnotetext{
26 Por. H. Arendt, O rewolucji, tłum. M. Godyń, Warszawa 2003, s. 84.
} 
To Rewolucja Francuska postawiła na eudajmonistycznie pojętą ideę równości w znaczeniu równej redystrybucji dóbr, wyrównywania warunków życiowych. Również w tym punkcie Arendt uwypukla różnicę wobec starożytnego ujęcia równości jako równości wobec prawa. Dla starożytnych izonomia zapewniała równość (isotes) ludziom nie dlatego, że z natury rodzą się równi, lecz dlatego, że z natury nie są równi. W antyczną myśl polityczną wpisana była zatem jako jej nieodłączny element różnica antropologiczna. Przychodząc na świat, ludzie diametralnie różnią się między sobą potrzebują więc sztucznych instytucji, które przynajmniej częściowo zniwelują wyjściowe nierówności.

Dla francuskich rewolucjonistów głównym imperatywem działania stała się idea zniesienia nędzy - stanu permanentnego braku i biedy, który zamyka uciśnionych $\mathrm{w}$ nieprzekraczalnym, złowieszczym kręgu konieczności. Jednakże ten pro-równościowy zapał doprowadził, zdaniem Arendt, do tego, że wraz z biedotą na rewolucyjną scenę wkroczyła przemoc wykorzystywana jako przedpolityczny sposób rozwiązywania problemów związanych z biologicznym przetrwaniem.

Główną przyczyną eskalacji zbiorowej agresji, terroru nie była jednak skumulowana w tłumie frustracja, pragnienie odwetu, lecz - paradoksalnie - współczucie (i powiązane z nim emocje), które stało się swoistym imperatywem określającym i uzasadniającym rewolucyjne praktyki. Według Arendt, współodczuwanie (współcierpienie i współradowanie się) jest bez wątpienia wartościową postawą emocjonalną zarówno $\mathrm{w}$ sferze moralnego działania, jak i w dziedzinie intymnych relacji międzyludzkich, ale przeniesione do przestrzeni politycznej przeobraża się w niezwykle skuteczny czynnik destrukcji ${ }^{27}$. Jego destrukcyjność płynie stąd, że nie daje się pogodzić ono z pluralizmem, z wielością perspektyw definiującą autentyczną politykę. W ostatecznej instancji empatia nie tylko nie potrzebuje argumentów, racji (gdyż apeluje do niezaprzeczalnej, bezdyskusyjnej oczywistości uczucia), lecz w pewnym sensie paraliżuje wszelką deliberację, wszelki spór wynikający z różnicy poglądów, postaw czy interesów. Gdy staje się naczelnym imperatywem działania politycznego, wymusza decyzje, które nie liczą się z logiką racjonalnego dyskursu, ponieważ stoi za nimi „emocjonalna prawda”, prawo serca, a nie beznamiętna dyscyplina kalkulującego rozumu.

Negatywny wpływ „tyranii współczucia” na Rewolucję Francuską polegał również na tym, że rewolucjoniści odwoływali się do niego, próbując rozwiązać problem braku legitymizacji wprowadzonych zmian ustrojowych. Zainaugurowanie nowego początku wiązało się z koniecznością powołania nowego, prawomocnego rządu, z koniecznością uchwalenia nowej konstytucji, a zatem ustanowienia nowego porządku prawnego. Konieczność ta rodziła jednak problem legitymizacji - czy-

27 Ibidem, s. 86. 
li problem z wyjaśnieniem faktu, że ludzie, którzy nie byli uprawnieni (przez konstytucję) do ustanawiania nowych rządów i praw, a zatem byli pozbawieniu autorytetu, tworzyli mimo wszystko od samych podstaw nowy ład polityczny. Jak pisze Arendt: „,Z teoretycznego punktu widzenia problem ten [...] przypomina błędne koło, gdzie ludzie zbierający się razem, by ukonstytuować nowy rząd, sami są czymś niekonstytucyjnym, nie mają zatem autorytetu, który pozwoliłby im wykonać to, co zamierzyli. Takie błędne koło pojawia się w sferze legislacji nie przy okazji zwykłego prawodawstwa, lecz tam, gdzie wydawane jest prawo zasadnicze, prawo kraju, czyli konstytucja, mająca od tej pory ucieleśniać "prawo wyższe«, z którego wszystkie inne prawa czerpią swój autorytet. [...] Kłopot polegał na tym, że aby umieścić prawo ponad człowiekiem i tym samym ustalić podstawę dla tworzonych przezeń praw"28. W sukurs przyszedł rewolucjonistom imperatyw współczucia, bezwarunkowy nakaz solidaryzowania się z wolą cierpiącego ludu. Ta strategia legitymizacyjna doprowadziła, zdaniem Arendt, do ostatecznego fiaska rewolucji, do faktycznego zniszczenia przestrzeni politycznej.

Początkowo bojownicy rewolucji nie występowali przeciwko wyzyskowi i nędzy, lecz przeciwko uciskowi i tyrani, żądając praw dla ludu, z którego przyzwolenia wywodzi się wszelka władza. Rewolucjoniści czuli, że należą do ludu, nie potrzebowali więc solidarności z nim, chcieli go jedynie reprezentować, ale gdy przewrót został dokonany, okazało się, że wyzwolenie od tyrani przyniosło wolność tylko nielicznym. Należało więc jeszcze raz wyzwolić większość nadal pogrążoną w nędzy. W tym momencie na scenę polityczną wkroczyło współczucie - rewolucjoniści musieli odtąd wyzwolić w sobie cnotę solidarności, która wyrażała się w trosce o pomyślność ludu i w dążeniu do utożsamienia własnej woli z wolą ludu. Paląca stała się potrzeba scalenia partykularnych celów, interesów w formie jednej, niepodzielnej woli, a za główny cel działań politycznych uznano szczęście ogółu, a nie - jak wcześniej wolność. Osobista legitymizacją tych, którzy reprezentowali lud, opierała się na „współczującej gorliwości”, czyli zdolności do cierpienia z ubogimi. Współczucie urosło do rangi najważniejszej cnoty politycznej.

Arendt przekonuje, że ta zmiana w postawie rewolucyjnej nastąpiła dopiero wtedy, gdy żyrondystom nie udało się stworzyć konstytucji i ustanowić rządu republikańskiego, a zatem gdy jakobini pod przywództwem Robespierre’a przejęli władzę i przestali interesować się formami ustrojowymi. Tym samym w praktyce politycznej doszło do przesunięcia akcentu z republiki na cierpiący, zdeklasowany lud (peuple) jako ostateczne źródło demokratycznej suwerenności. Wyobrażenie suwerena łączyło w sobie zatem doświadczenie nędzy i nakaz współczucia: „Tam, gdzie nie ma nieszczęścia, nie ma też i litości (Mitleid),

28 Ibidem, s. 229. 
dlatego zależy ona od istnienia ludzi nieszczęśliwych tak samo jak pragnienie władzy i siły zależy od istnienia słabych. Poza tym litość jako sentyment - może dawać zadowolenie sama w sobie, a to niemal automatycznie prowadzi do gloryfikacji jej przyczyny, czyli cierpienia innych"29. Jeśli zatem współczucie stanowi element legitymizacji demokratycznej suwerenności, wówczas nie można zlikwidować nędzy społecznej, nie naruszając równocześnie źródeł prawomocności tej władzy. Według Arendt, ta performatywna sprzeczność zawarta w samym pojęciu suwerena jako cierpiącego ludu zadecydowała o niestabilności nowej władzy, a zasadniczo o „antypolitycznej naturze” nowego porządku politycznego.

Filozofka wskazuje ponadto, że teoretycznym źródłem owego przesunięcia akcentu politycznego $\mathrm{z}$ zagadnień prawno-ustrojowych na kwestie socjalne była koncepcja woli powszechnej Rousseau, która zastąpiła antyczne pojęcie ugody: „O wiele ważniejsze jest to, że samo słowo ugoda, w którym brzmią pojęcia świadomego wyboru i przemyślanej opinii, zastąpiono słowem wola, z definicji wykluczającym wszelkie procesy wymiany opinii i ewentualnej zgodności między nimi"30. Arendt przekonuje, że jakobini dali uwieść się obrazowi jednej niepodzielnej woli, która łączy w sobie wszystkie partykularne wole, z góry uniemożliwiając prowadzenie jakiejkolwiek rzeczowej debaty. Trwałość państwa miała być zatem gwarantowana nie przez instytucje publiczne, lecz przez wolę ludu (volonté générale) utożsamioną przez Robespierre'a z opinią powszechną. Za Rousseau jakobini pojmowali naród na podobieństwo ciała kierowanego przez jedną wolę, wierząc, że postulowana przez nich organiczna całość może powstać tylko wówczas, gdy naród zjednoczy się w obronie przed zewnętrznym wrogiem (polityka międzynarodowa) i przed wrogiem wewnętrznym: partykularnymi interesami obywateli, które popadają w sprzeczność z wolą powszechną.

Według Arendt, u podłoża takiej monistycznej wizji kryło się milczące założenie, że volonté générale jest rodzajem automatycznej artykulacji interesu ludu jako całości. Powszechny cel, który powinien przyświecać wszystkim obywatelom bez wyjątku, wyłania się tym samym spontanicznie i bezwiednie, zderzając się z partykularnymi celami poszczególnych jednostek. Aby móc partycypować w realizowaniu wspólnego celu, jednostka musi zatem zbuntować się przeciwko samej sobie i nieprzerwanie trwać w tym buncie. Tego rodzaju „totalna wewnętrzna mobilizacja", utrzymywany w stanie ciągłego pogotowia niepokój i podejrzliwość stanowiły, zdaniem filozofki, afektywny fundament rewolucyjnego terroru. Walkę z własnym egoizmem, z partykularyzmem własnej woli rewolucjoniści utożsamiali z cnotą bezinteresowności.

29 Ibidem, s. 108.

30 Ibidem, s. 91. 
Decydujące znaczenie w projekcie politycznym Robespierre’a miała zatem niestrudzenie tropiąca w każdym obywatelu hipokryzję, "zaciekle" bezinteresowna postawa współczucia dla uciśnionego ludu ${ }^{31}$. Znajdujący się u władzy rewolucjoniści uważali, że źródłem tego współczucia nie może być kalkulujący, egoistyczny z natury rozum (Rousseau), lecz zdolność do głębokiego współcierpienia i bezgraniczna żarliwość.

Efektem takiej afektywnej redefinicji sfery polityczności okazał się, jak już wspomnieliśmy, całkowity rozpad publicznych instytucji, a tym samym zaprzepaszczenie właściwego celu rewolucji, jakim było i jest, zdaniem Arendt, ustanowienie przestrzeni intersubiektywnej wolności. Zuniwersalizowana empatia kierowana ideą powszechnego szczęścia i dobrobytu przerodziła się $\mathrm{w}$ swoje przeciwieństwo - nieznoszący sprzeciwu, paranoiczny terror.

Przykład rewolucji jest dla nas o tyle znamienny, że bardzo wyraźnie pokazuje podatność humanitarystycznych idei na instrumentalizację. Empatia, jak dowodzi Arendt, jest zawsze odniesiona do konkretnego, uchwytnego empirycznie przypadku, niepowtarzalnej osoby i może rozwijać się wyłącznie w sferze intymnych powiązań międzyludzkich, gdy natomiast staje się narzędziem polityki, jej obiekt zatraca jednostkowe kontury, staje się niedostępną dla doświadczenia abstrakcją. Współczucie przekształcone $\mathrm{w}$ bezosobową litość, $\mathrm{w}$ instrument politycznej agitacji niepostrzeżenie otwiera śluzy dla nieokiełznanych żywiołów przemocy i zbiorowej agresji. Przypadek Robespierre'a stanowi ostrzeżenie, które wprawdzie płynie do nas z dość odległej przeszłości, ale wydaje się być nadal aktualne zwłaszcza w odniesieniu do populistycznych projektów polityki społecznej, które rezygnują z merytorycznej debaty i żmudnego, pełnego kompromisów dążenia do konsensu na rzecz „sentymentalnej” retoryki równości i solidarności. Jak pisze Arendt: „To, co może naprawdę było pasja przekształciło się teraz w bezgraniczną emocję, która aż nadto trafnie zdawała się odzwierciedlać bezgraniczne cierpienie mas, przytłaczających samą są liczebnością. Tym samym Robespierre'a utracił zdolność nawiązywania i utrzymywania stosunków z konkretnym osobami. Ocean cierpienia wokół niego i wzburzone morze emocji w nim zatopiły wszystkie szczegółowe względy: zarówno względy przyjaźni, jak też wzgląd na sztukę polityczną i zasadę działania" 32 .

Współczesne demokracje liberalne stanowią niewątpliwie oazy względnego dobrobytu na bezbrzeżnej pustyni cierpienia i nędzy. Przymusowa demokratyzacja krajów słabiej rozwiniętych pod względem gospodarczym i zazwyczaj całkowicie odmiennych kulturowo nie przynosi w praktyce poprawy ich sytuacji materialnej, lecz budzi wrogość,

31 Por. ibidem, s. 96.

32 Ibidem, s. 109. 
potrzebę buntu "przegranych” społecznie i ekonomicznie mas, które zostały wykluczone ze wspólnoty „błogiej konsumpcji”, a nie posiadają możliwości dochodzenia swoich praw na drodze przyjętych w demokracji zasad i procedur. Codzienne wiadomości ze świata pokazują jak łatwo rozpalają się iskry zbiorowego niezadowolenia i frustracji, a co najbardziej niepokojące, pokazuja jak łatwo cierpienie poddaje się manipulacji, zwłaszcza wtedy, gdy posługuje się ona emocjonalną retoryką współczucia i „słusznego" gniewu wobec tych, którym "niesłusznie” się powiodło.

\section{Streszczenie}

\section{Konserwatywna krytyka humanitaryzmu. Część druga Max Scheler, Hannah Arendt}

\section{Słowa kluczowe}

Humanitaryzm; Scheler; Arendt; resentyment; współczucie; miłość bliźniego; polityka; moralność; miłość; rewolucja

W drugiej części cyklu artykułów poświęcony krytyce humanitaryzmu zostanie przedstawione stanowisko M. Schelera i H. Arendt. Scheler skupia się na ukazaniu fundamentalnej różnicy między etyką chrześcijańską a oświeceniowym egalitaryzmem, miedzy etyką miłości chrześcijańskiej a świecką etyką umiłowania ludzkości. Arendt przeprowadza natomiast krytykę ekonomizacji i „,socjalizacji” współczesnej polityki. Filozofka wpisuje etos humanitaryzmu w szerszy kontekst zmian społecznych i politycznych, obarczając go "winą" za upadek sfery publicznej i błędy nowoczesnych rewolucji, które zapoznały swój „prawdziwie” emancypacyjny potencjał.

\section{Summary}

\section{Conservative critics of humanitarianism. Second part Max Scheler, Hannah Arendt}

\section{Keywords}

humanitarianism; Scheler; Arendt; ressentiment; compassion; charity; politics; morality; love; revolution 
In the second part of the series of articles devoted to criticism of humanitarinism will be presented the position of M. Scheler and H. Arendt. Scheler focuses on showing the fundamental difference between Christian ethics and the Enlightenment egalitarianism, thus between the spiritual Christian love and the secular love of humanity. Hannah Arendt carries out the criticism of economization and the "socialization" of contemporary politics. She fits the ethos of humanity in the broader context of social and political change, blaming its "guilt" for the collapse of the public sphere and errors of modern revolution, which missed its "true" emancipatory potential.

\section{Bibliografia}

Arendt Hannah, Kondycja ludzka, tłum. A. Łagodzka, Warszawa 2000.

Arendt Hannah, O rewolucji, tłum. M. Godyń, Warszawa 2003.

Scheler Max, Resentyment a moralność, tłum. J. Garewicz, Warszawa 1977.

Scheler Max, Istota i formy sympatii, tłum. A. Węgrzecki, Warszawa 1986.

Scheler Max, Stanowisko człowieka w kosmosie, tłum A. Węgrzecki, w: Pisma $z$ antropologii filozoficznej $i$ teorii wiedzy, Warszawa 1987. 